\title{
Cops at War: How World War II Transformed U.S. Policing - Corrigendum
}

\author{
Stuart Schrader
}

DOI: https://doi.org/10.1017/mah.2021.12; Published online by Cambridge University Press June 28, 2021

In the original publication of Schrader (2021), information from footnote 4 was omitted. The correct footnote 4 is reproduced in its entirety below:

${ }^{4}$ New historical literature on U.S. policing includes Christopher L. Agee, The Streets of San Francisco: Policing and the Creation of Cosmopolitan Liberal Politics, 1950-1972 (Chicago, 2014); Simon Balto, Occupied Territory: Policing Black Chicago from Red Summer to Black Power (Chapel Hill, NC, 2019); Max Felker-Kantor, Policing Los Angeles: Race, Resistance, and the Rise of the LAPD (Chapel Hill, NC, 2018); Schrader, Badges Without Borders; Seigel, Violence Work; and Carl Suddler, Presumed Criminal: Black Youth and the Justice System in Postwar New York (New York, 2019). By comparison, the British, Dutch, and Belgian experiences during the Second World War have received scrutiny. See Clive Emsley, Exporting British Policing during the Second World War: Policing Soldiers and Civilians (London, 2017); Cyrille Fijnaut, ed., The Impact of World War II on Policing in North-West Europe (Leuven, Belgium, 2004). On policing and empire across the hiatus of the Second World War, see David Anderson and David Killingray, eds., Policing and Decolonisation: Politics, Nationalism, and the Police, 1917-65 (Manchester, UK, 1992); and Alfred W. McCoy, Policing America's Empire: The United States, the Philippines, and the Rise of the Surveillance State (Madison, WI, 2009). An important exception to the paucity of scholarship on US policing during World War II is Emily Brooks's work: Emily Brooks, “A War Within a War': Policing Gender and Race in New York City during World War II" (PhD dissertation, City University of New York, 2019), and Emily Brooks, "Rumor, Vicious Innuendo, and False Reports': Policing Black Soldiers in Wartime Staten Island," Journal of Urban History, advance online publication, January 26, 2020, https://doi.org/10.1177/ 0096144219900134.

\section{Reference}

Schrader, S. (2021). Cops at War: How World War II Transformed U.S. Policing. Modern American History, 4(2), 159-179. doi:10.1017/mah.2021.12 